\title{
Rudymentarne zasady życia społecznego w ujęciu Edmunda Wnuka-Lipińskiego'
}

\section{Wstęp}

$\dot{Z}$

ycie społeczne opiera się na różnych wartościach i zasadach, które są jednym z filarów zdrowo funkcjonującego społeczeństwa. Egzystencja jakiejkolwiek wspólnoty wymaga respektowania różnych ogólnoprzyjętych norm społecznych. W życiu publicznym zajmowane są różnorakie stanowiska (np. indywidualistyczne, personalistyczne, komunitariańskie), przyznające priorytet jednym wartościom i zasadom, a pomniejszające rolę innych kategorii. Tymczasem demokracja bez uwzględnienia wymiaru normatywno-aksjologicznego straciłaby rację bytu. Różni autorzy odmiennie interpretują zasady życia społecznego oraz przyznają im zróżnicowaną rangę. Jednym ze znanych badaczy, którzy podejmują ten temat, jest Edmund Wnuk-Lipiński, stąd klucz doboru owych zasad będzie łączył się z polem badawczym omawianego autora.

Celem niniejszego artykułu jest próba eksplikacji stanowiska E. Wnuka-Lipińskiego, które dotyczy podstawowych zasad społecznych. Na początku

* Dr Monika Dobrogowska - Katedra Socjologii Struktur, Procesów Społecznych i Pracy Socjalnej, Katolicki Uniwersytet Lubelski Jana Pawła II, e-mail: monika.dobrogowska@kul.pl, ORCID: 0000-0002-1219-3546.

${ }^{1}$ Edmund Wnuk-Lipiński (1944-2015) - profesor, dr habilitowany, socjolog. Dyrektor Instytutu Studiów Politycznych PAN, założyciel Katedry Socjologii w Collegium Civitas. Działacz społeczny, m.in. doradca do spraw polityki społecznej NSZZ „Solidarność”, w latach 1989-1991 kierownik zespołu doradców naukowych przy Obywatelskim Klubie Parlamentarnym. Niektóre z jego znanych publikacji: Demokratyczna rekonstrukcja. Z socjologii radykalnej zmiany ustrojowej (PWN, Warszawa 1996); Granice wolności. Pamiętnik polskiej trans-formacji (Scholar, Warszawa 2003); Świat międzyepoki. Globalizacja, demokracja, państwo narodowe (Znak, Kraków 2004); Socjologia życia publicznego (Scholar, Warszawa 2005). 
zostanie wyjaśnione samo pojęcie zasady społecznej. Następnie będą omówione takie kwestie jak: zasada dobra wspólnego, solidarności, pomocniczości oraz zaufania społecznego - głównie na gruncie nauki polskiej oraz ze szczególnym uwzględnieniem stanowiska E. Wnuka-Lipińskiego.

\section{Pojęcie zasady społecznej}

Koncepcja zasad społecznych jest przedmiotem zainteresowania przedstawicieli personalizmu społecznego. Czesław Strzeszewski wyjaśnia, że „zasada społeczna jest równocześnie zasadą ontologiczną, moralną i prawną. Z jej charakteru ontologicznego wynika, iż obowiązuje wszystkie społeczności ludzkie, gdyż jej normą jest prawo naturalne”2. Autor dodaje też, że „w zasadzie społecznej zawarta jest norma moralna, stąd występuje w niej pierwiastek powinnościowy, wskazuje ona prawa i obowiązki społeczne człowieka, wskazuje hierarchię wartości moralnych. Jej realizacja w życiu społecznym czy politycznym wymaga również normy prawnej, dzięki której może uzyskać konieczną sankcję publiczno-prawną" 3. Józef Majka twierdzi, że zasady życia społecznego „są to ogólne dyrektywy dotyczące istnienia i normalnego funkcjonowania społeczeństwa w takim sensie, że łamanie lub omijanie tych dyrektyw albo musi zagrozić życiu społecznemu, albo oznacza, że mamy do czynienia ze społecznością pozorną"“. Według tego autora, zasady społeczne rozumiane są niekoniecznie w znaczeniu nakazów czy norm moralnych, bo te zależą od moralnych zobowiązań względem danej społeczności ${ }^{5}$. Zasady te mają również znaczenie poznawcze, bo ułatwiają odróżnianie społeczności rzeczywistej od pozornej ${ }^{6}$. Jan Krucina pisze, że zasady społeczne są normami moralności i i wyrażają sądy normatywne. Z kolei w sądach tych zawarta jest „powaga idealnej powinności”" . Jerzy Koperek wyjaśnia, że „każda zasada społeczna ma swój metafizyczny punkt oparcia w społecznej naturze człowieka, jest zakotwiczona w istocie życia społecznego i funkcjonuje w organizacyjnej sferze tego życia"s. Zasady społeczne nie są oderwane od

${ }^{2}$ C. Strzeszewski, Katolicka nauka społeczna, RW KUL, Lublin 1994, s. 512.

3 Tamże.

${ }^{4}$ J. Majka, Filozofia społeczna, ODiSS, Warszawa 1982, s. 165.

${ }_{5}$ Tamże, s. 166.

6 Tamże.

7 J. Krucina, Dobro wspólne. Teoria i jej zastosowanie, Wydawnictwo Wrocławskiej Księgarni Archidiecezjalnej, Wrocław 1972, s. 112.

${ }^{8}$ J. Koperek, Zasady życia społecznego, w: Słownik społeczny, red. B. Szlachta, WAM, Kraków 2004, s. 1605. Podobnie jak C. Strzeszewski i J. Koperek, zasadę społeczną interpretuje Jan Szymczyk. Twierdzi on, że zasada społeczna ma charakter ontologiczny, moralny i prawny. Charakter ontologiczny zakłada, że jej filozoficzne podstawy tkwią w społecznej naturze człowieka. Charakter moralny wiąże się z pewną powinnością, charakter prawny zaś oznacza, że musi być ustanowiona 
rzeczywistości. Nie są jedynie postulatem. Obowiązują one jednostki w relacji do wspólnoty, ale również wspólnoty w stosunku do jednostki.

Różni autorzy przypisują odmienną rangę zasadom społecznym. C. Strzeszewski wśród podstawowych zasad wylicza: wolność, pomocniczość, solidarność. J. Majka za najważniejszą uważa zasadę personalizmu, czyli godność osoby ludzkiej, z której wynikają zasady szczegółowe, takie jak: zasada wolności, pomocniczości, pluralizmu społecznego, sprawiedliwości, demokracji, prawdy, miłości społecznej. Wśród moralnych zasad życia społecznego ten sam autor proponuje: prawdę, zasadę pomocniczości, solidarności, sprawiedliwości społecznej, pokoju ${ }^{10}$. Z kolei wspomniany wcześniej J. Koperek twierdzi, że trzy podstawowe zasady kształtujące życie społeczne to: dobro wspólne, pomocniczość i solidarność ${ }^{11}$. Trudno doszukiwać się $\mathrm{w}$ pismach E. Wnuka-Lipińskiego definicji samego pojęcia zasady społecznej. Autor nie prowadzi również katalogu zasad społecznych. Jednak biorąc pod uwagę jego zainteresowania badawcze, prace naukowe oraz wypowiedzi eksperckie, można zauważyć, że stosunkowo dużo uwagi poświęca kategorii dobra wspólnego, solidarności oraz zaufaniu społecznemu.

\section{Zasada dobra wspólnego}

Jedną z zasad społecznych, jaką wymieniają m.in. przedstawiciele katolickiej nauki społecznej, jest dobro wspólne. Wielu autorów przyznaje priorytet tej kategorii. C. Strzeszewski definiuje je jako „dobro każdej osoby ludzkiej i wszystkich ludzi" ${ }^{2}$. W takim rozumieniu dobro wspólne jest celem społeczności politycznej, do której - z natury - należą wszyscy ludzie. Z punktu widzenia personalistycznej koncepcji dobra wspólnego składa się ono z dwóch elementów: wewnętrznego i zewnętrznego. Element wewnętrzny jest ontologiczno-aksjologiczny. Takim dobrem jest integralny rozwój ludzkiej osoby oraz wartości, które są do tego niezbędne. Element zewnętrzny ma charakter społeczno-instytucjonalny. Są to różne struktury, instytucje i warunki potrzebne do realizacji dobra wspólnego ${ }^{13}$.E. Wnuk-Lipiński kładzie nacisk przede wszystkim na aspekt zewnętrzny dobra wspólnego. Bonum commune odnosi on do konkretnej wspólnoty państwowej i traktuje jako pewien

\footnotetext{
i przestrzegana przez państwo (J. Szymczyk, Pojęcie zasady społecznej w kontekście dobra wspólnego w ujęciu przedstawicieli szkoły lubelskiej, „Roczniki Nauk Społecznych” 1997, t. 25, z. 1, s. 122-123).

${ }_{9}$ C. Strzeszewski, Zasada a prawo społeczne, „Roczniki Nauk Społecznych” 1994-1994, t. 22-23, z. 1, s. 138 .

${ }^{10}$ J. Majka, Filozofia społeczna..., s. $165 \mathrm{nn}$.

${ }^{11}$ J. Koperek, Zasady życia społecznego..., s. 1605.

12 C. Strzeszewski, Katolicka Nauka Społeczna..., s. 493.

13 J. Szymczyk, Immanentny i instrumentalny aspekt dobra wspólnego, „, Roczniki Nauk Społecznych" 1998 , t. 26, z. 1, s. 169-170.
} 
zbiór wartości, które mogą zyskaćakceptację wszystkich poważnych sił politycznych w kraju i jak najszerszego kręgu wyborców, niezależnie od ich zróżnicowanych preferencji politycznych. Dobro wspólne jest pewnym zasobem, niebędącym przedmiotem bieżących rozgrywek politycznych, ale depozytem normatywnym całej klasy politycznej i płaszczyzną spotkania w sytuacji głębokiego kryzysu wewnętrznego i zewnętrznego ${ }^{14}$. Wspomnianym przez autora depozytem normatywnym może być przykładowo racja stanu zdefiniowana przez konstytucję. Racja stanu, czyli nadrzędny interes narodowy - zdaniem E. Wnuka-Lipińskiego - jest niestety rozumiana rozmaicie, w zależności od wewnętrznej i zewnętrznej koniunktury politycznej ${ }^{15}$. Stąd też socjolog ten podejmuje próbę określenia elementów konstytuujących dobro wspólne, takie, które byłoby akceptowane zarówno przez elity rządzące, jak i przez samych obywateli. Omawiany autor prezentuje katalog wartości wchodzących w skład dobra wspólnego. Wśród wartości je konstytuujących E. Wnuk-Lipiński wymienia: niepodległośći suwerenność kraju ${ }^{16}$. Są to jego zdaniem wartości nadrzędne, ponieważ brak ich realizacji kwestionuje pozostałe wartości, czyli bezpieczeństwo zewnętrzne i wewnętrzne; integralność terytorialną; rozwój gospodarczy i cywilizacyjny; wolność jednostki rozumianą jako „wolność negatywną", a więc chronione prawem niepodleganie opresjom zewnętrznym; przeciwdziałanie marginalizacji społecznej, czyli działania państwa i instytucji pozarządowych mające na celu ograniczenie marginesu społecznego ${ }^{17}$. Według E. Wnuka-Lipińskiego wszelkie poczynania klasy rządzącej powinny opierać się na jasno zdefiniowanym dobru wspólnym, a nie na interesach partyjnych ${ }^{18}$. Z podobnego założenia wychodzą zwolennicy idei republikańskiej. Według nich - jak podkreśla J. Szymczyk - „poszczególne elementy państwa mają współdziałać ze sobą w duchu reguły «razem» - w obronie lub na rzecz dobra wspólnego, czyli państwa jako całości”"19. Dotyczy to zarówno elit rządzących, jak i obywateli.

O dobru wspólnym w sposób wielopłaszczyznowy traktuje J. Koperek. Uważa on, że odnosi się ono w największym stopniu do państwa i społeczności

14 E. Wnuk-Lipiński, Demokratyczna rekonstrukcja. Z socjologii radykalnej zmiany ustrojowej, Wydawnictwo Naukowe PWN, Warszawa 1996, s. 272.

15 Tamże. Zdaniem E. Wnuka-Lipińskiego pojęciem bliskoznacznym, dobra wspólnego jest „racja stanu”, którą definiuje on jako ogół podstawowych interesów wspólnoty politycznej zorganizowanej w formie państwa, wyznaczających długofalowe priorytety polityki zagranicznej oraz niektóre priorytety polityki wewnętrznej. „Dobro wspólne” ma nieco szerszy zakres, ponieważ bardziej uwzględnia priorytety polityki wewnętrznej państwa (E. Wnuk-Lipiński, Polityka, w: Encyklopedia socjologii, t. 3, red. H. Domański i in., Oficyna Naukowa, Warszawa 2000, s. 138).

16 E. Wnuk-Lipiński, Demokratyczna rekonstrukcja..., s. 272.

17 Tenże, Polityka..., s. 138.

18 Należy przywrócić ład moralny [z E. Wnukiem-Lipińskim rozmawiali Amelia Łukasiak i Cezary Bielakowski], „Newsweek” 2005, nr 12, s. 26-27.

19 J. Szymczyk, Rudymentarne wartości republikańskie. Zarys problematyki, w: Segmenty aktywności społecznej a wartości. Idee i praktyka, red. J. Szymczyk, Wydawnictwo KUL, Lublin 2012, s. 127. 
ludzkości. „Przedmiotowa treść dobra wspólnego społeczności państwowej nie dotyczy dobra abstrakcyjnego, ale stanowi wartość obiektywną, odrębną od celów społeczności pośrednich, a jednocześnie nadrzędną i ujmującą w sobie dobra poszczególnych społeczności i osób jako integralne składniki”20. Nie jest to dobro jakiejś części obywateli ani dobro publiczne, ani fikcyjne, tylko dobro każdego obywatela i każdej wspólnoty wchodzącej w skład wspólnoty państwowej, dzięki któremu człowiek może się rozwijać. J. Koperek wymienia podstawowe elementy dobra wspólnego: porządek prawno-społeczny, zespół dóbr ekonomicznych, zespół instytucji z dziedziny kultury, oświaty i wychowania.

Dobro wspólne jako zasadę społeczną interpretuje również J. Szymczyk, rozpatrując ją we wspomnianych już wcześniej perspektywach: ontologicznej, prawnej i moralnej. Lubelski socjolog ontologiczny charakter dobra wspólnego widzi w ugruntowaniu go w samej naturze społecznej człowieka. Człowiek jest bytem samodzielnym i osobowym, a celem społeczności jest doskonalenie i rozwój osoby ludzkiej ${ }^{21}$. Charakter moralny oznacza, że dobro człowieka jest treścią dobra wspólnego całej społeczności, ale też normą moralności społecznej. Co więcej, dobro wspólne każdej społeczności ma charakter autonomiczny i może być osiągane w sposób niezależny, ale z poszanowaniem nadrzędnego w hierarchii dobra wspólnego, np. państwa ${ }^{22}$. Z kolei dobro wspólne jako zasada prawna wskazuje, że prawa osobowe są źródłem wszystkich kategorii praw społecznych $^{23}$. Bonum commune wyznacza obowiązki i uprawnienia, począwszy od jednostki aż po społeczność państwową.

Niemniej, zarówno w myśli republikańskiej, personalistycznej, jak i u E. Wnuka-Lipińskiego, istnieje - w porządku naturalnym - prymat dobra wspólnego nad dobrem partykularnym, jednostkowym, pod warunkiem, że są to dobra tego samego rodzaju. $\mathrm{Z}$ kolei $\mathrm{w}$ sensie nadprzyrodzonym, transcendentnym dobro osoby nigdy nie może być podporządkowane dobru wspólnemu. Ten pogląd akcentuje katolicka nauka społeczna. Z perspektywy pierwszej sytuacji (porządku doczesnego) można stwierdzić, iż dbając o dobro wspólne, obywatele jednocześnie realizują swoje dobro jednostkowe. Można to robić poprzez życie we wspólnocie, dzięki czemu obywatele, jak zauważa J. Szymczyk, rozwijają swoją osobowość ${ }^{24}$ albo też, jak twierdzi E. Wnuk-Lipiński, rozwijają podmiotowość sprawczą ${ }^{25}$.

${ }^{20}$ J. Koperek, Dobro wspólne, w: Słownik społeczny, red. B. Szlachta, WAM, Kraków 2004, s. 144.

${ }^{21}$ J. Szymczyk, Dobro wspólne a prawa człowieka w ujęciu przedstawicieli lubelskiej szkoły katolickiej nauki społecznej, w: Pomiędzy etyka a polityką, red. E. Hałas, TN KUL, Lublin 1999, s. 281.

22 Tamże.

${ }^{23}$ Tamże, s. 280.

${ }^{24}$ J. Szymczyk, Rudymentarne wartości republikańskie..., s. 129.

${ }^{25}$ E. Wnuk-Lipiński, Socjologia życia publicznego, Scholar, Warszawa 2005, s. 79 nn. Podmiotowość sprawczą E. Wnuk-Lipiński rozumie jako „zakres autonomicznych decyzji jednostki, formujących 
Warszawski socjolog jasno określa istotę i zakres dobra wspólnego. Jednak są autorzy, dla których zagadnienie to nie wydaje się tak oczywiste. Na przykład Joseph A. Schumpeter, do którego wywodów sięga E. Wnuk-Lipiński, analizując zjawiska socjologii życia publicznego, o dobru wspólnym pisze przez pryzmat demokracji, którą definiuje następująco: „metoda demokratyczna jest rozwiązaniem instytucjonalnym służącym wypracowaniu decyzji politycznych, które realizuje wspólne dobro, sprawiając, że ludzie sami decydują o różnych sprawach w drodze wyboru jednostek zbierających się w celu wykonywania woli ludu" ${ }^{26}$. Definicja ta implikuje dwa zagadnienia: wolę ludu oraz dobro wspólne. J.A. Schumpeter kwestionuje oba elementy. Podważa istnienie dobra wspólnego, gdyż nie wiadomo, jego zdaniem, czym ono jest i kto miałby je określać. Z tej racji stwierdza - w przeciwieństwie do E. Wnuka-Lipińskiego - że „nie istnieje coś takiego jak jednoznacznie określone wspólne dobro, na które wszyscy mogliby się zgodzić"27. Na inny aspekt, pominięty przez E. Wnuka-Lipińskiego, zwraca uwagę Mirosława Grabowska. Mianowicie, nawet jeśli członkowie małej wspólnoty rozpoznaliby dobro wspólne, to - jak zauważa polska socjolog - pozostaje problem współczesnych, rządzonych demokratycznie, dużych społeczności, często zróżnicowanych rasowo, etnicznie, kulturowo, religijnie ${ }^{28}$. Wydaje się, że odpowiedź na ten problem odnajduje J. Szymczyk. Według lubelskiego uczonego „konkretne dobro wspólne każdej społeczności wyraża się inaczej w zależności od natury i charakteru danej społeczności. Dla każdej jednak z nich jest ono jednoznacznie określone i ono właśnie wyznacza zakres uprawnień i obowiązków danej społeczności w stosunku do jej członków"29.

Paweł Śpiewak pesymistycznie zauważa, że we współczesnej myśli i filozofii politycznej nie wspomina się o dobru wspólnym. Dziś kategoria ta, będąca niegdyś podstawą refleksji o państwie, znikła niemal całkowicie. Autor poszukuje przyczyn takiego stanu rzeczy. Według niego w dzisiejszym świecie jest tak wiele ideałów i wzorców, że nie sposób wskazać na dobro lub dobra, do którego powinny dążyć wspólnoty. Ponadto koncepcję dobra wspólnego trudno pogodzić z teoriami demokracji, ponieważ dobro wspólne byłoby ponad wolą ludu wyrażoną w wyborach i ponad konstytucją. Wtedy nie wiadomo, kto i jak miałby je wypowiadać. Co więcej, zasada ta ma zbyt konserwatywny, archa-

jej postawy czy zachowania, które podejmowane są mimo uwarunkowań kontekstu społecznego (a niekiedy nawet wbrew tym uwarunkowaniom)" (tamże, s. 80).

${ }^{26}$ J. Schumpeter, Kapitalizm, socjalizm, demokracja, Wydawnictwo Naukowe PWN, Warszawa 2009, s. 312.

27 Tamże, s. 314.

28 M. Grabowska, T. Szawiel, Demokracja, w: M. Grabowska, T. Szawiel, Budowanie demokracji. Podziały społeczne, partie polityczne i społeczeństwo obywatelskie $w$ postkomunistycznej Polsce, Wydawnictwo Naukowe PWN, Warszawa 2001, s. 75.

29 J. Szymczyk, Dobro wspólne a prawa człowieka..., s. 279. 
iczny charakter, gdyż powstała ona w dawnych czasach i nie pasuje do szybko zmieniającego się świata i złożoności życia publicznego ${ }^{30}$. Jednak P. Śpiewak poszukuje recepty na poprawę tej sytuacji i proponuje, by obywatele rozbudzili w sobie cnotę roztropności, by wyszli z izolacji, oderwali się od kultu pieniądza, od trosk związanych z codziennymi sprawami i zbliżyli się do siebie, wspólnie myśleli i działali, aby zaczęli praktykować wolność polityczną ${ }^{31}$. Te wszystkie postulaty autor rozumie jako publiczną aktywność, dzięki której dobro wspólne zaistnieje w świadomości obywateli, a nie będzie mitycznym postulatem. Taką właśnie aktywność obywatelską, mającą na celu dążenie do rozwijania idei bonum commune, jak zauważa J. Szymczyk, postulują przedstawiciele myśli republikańskiej. Według niej dla demokracji ważna jest m.in. strategia kontestacji, czyli możliwość zgłaszania sprzeciwu wobec zarządzeń, ustaw, nakazów $w_{ł a d z y}{ }^{32}$. Stąd też republikanie proponują dążenie do dobra wspólnego, a w zasadzie uzgadnianie go poprzez ścieranie się różnych racji, stanowisk, debat, toczenie sporów na argumenty. W ten sposób omawiana zasada jawi się jako czynnik rozwijający republikę ${ }^{33}$. E. Wnuk-Lipiński również uwzględnia taki sposób podejmowania decyzji w demokracji liberalnej i nazywa to „demokracją interakcyjną"34, szerzej znaną jako demokracja deliberacyjna.

\section{Zasada pomocniczości}

Inną ważną zasadą życia społecznego jest zasada pomocniczości. C. Strzeszewski wyjaśnia, że zasada ta ma charakter zarówno ontologiczny, prawny, jak i moralny. Autor zaznacza, że „każda więc społeczność ma charakter służebny i celowy, jej celem jest służyć człowiekowi przez zaspokajanie pewnej kategorii jego potrzeb” ${ }^{35}$. Zasada subsydiarności jest zasadą prawną, ponieważ „pomocniczość wskazuje, że prawa osobowe są źródłem wszystkich praw społecznych. (...) wszystkie społeczności naturalne, takie jak rodzina, zawód, naród, państwo itd. mają samodzielne, niezależne od siebie prawa ugruntowane w prawie naturalnym poprzez naturę człowieka" ${ }^{36}$. C. Strzeszewski zaznacza, że - zgodnie

30 P. Śpiewak, Dobro wspólne to publiczna aktywność, w: Dobro wspólne. Gdański Areopag - Forum Dialogu, 9-11 listopada 2001, Gdańsk, red. W. Bock, Biuro Prasowe Arcybiskupa Metropolity Gdańskiego, Gdańsk 2002, s. 71.

31 Tamże, s. 72. O roztropności E. Wnuk-Lipiński szerzej pisze w publikacji: Czy $w$ dzisiejszej Polsce istnieje zapotrzebowanie na roztropność?, w: Roztropność, red. Z. Żelazek, Forum Dialogu Gdański Areopag, Gdańsk 2011, s. 53-75.

32 J. Szymczyk, Rudymentarne wartości republikańskie..., s. 130-131.

33 Tamże, s. 131.

${ }^{34}$ E. Wnuk-Lipiński, Demokratyczna rekonstrukcja..., s. 48.

35 C. Strzeszewski, Katolicka nauka społeczna..., s. 517.

36 Tamże. 
z tą zasadą - każda społeczność mniejsza odwołuje się do pomocy społeczności większych tylko wtedy, gdy nie może spełnić wszystkich zadań wyznaczonych jej przez potrzeby jej członków. A każda społeczność wyższa musi szanować potrzeby społeczności niższych ${ }^{37}$. Zasada pomocniczości jest również zasadą moralną, gdyż wskazuje hierarchę wartości moralnych, ponieważ „osoba ludzka jest celem życia społecznego, a więc jej dobro jest treścią dobra społecznego i normą moralności społecznej" ${ }^{38}$. Istotę zasady subsydiarności precyzuje J. Szymczyk, pisząc: „pomagać tak, aby (...) podmioty mogły z biegiem czasu same w sposób autonomiczny, odpowiedzialny i dojrzały zaktywizować swoje siły i wydobyć drzemiące możliwości do realizacji własnych celów i zadań" ${ }^{39}$. Wspomniane podmioty to osoby ludzkie i mniejsze społeczności. Zasada subsydiarności dobrze wpisuje się w kategorię demokracji i wolnego rynku, łączy się z ideą państwa pomocniczego ${ }^{40}$. Lubelski socjolog Stanisław Kowalczyk w kontekście państwa demokratycznego również zauważa: „tyle wolności ile można, tyle interwencji państwa - ile to konieczne" ${ }^{\prime 1}$. Takie podejście nie ogranicza podmiotów, dotyczy jedynie wsparcia okazjonalnego i umożliwia w dalszej perspektywie wolne działanie.

E. Wnuk-Lipiński pisząc o zasadzie pomocniczości, nie próbuje jej zdefiniować, lecz przedstawia ją w sposób pośredni, prezentując elementy takiej koncepcji, np. rolę państwa czy istnienie podmiotów pośrednich między państwem a obywatelami ${ }^{42}$. Omawiany autor łączy subsydiarność m.in. z polityką społeczną państwa. Jego zdaniem „polityka społeczna, rozumiana jako proces redystrybucji, jest podejmowana w celu korekty tych procesów gospodarczych i społecznych, które naruszają zespół wartości definiowanych jako «sprawiedliwość społeczna»"43. Innymi słowy, polityka społeczna państwa powinna przebiegać tak, żeby korygować efekty czystych mechanizmów rynkowych, tym samym redukować nierówności społeczne, które przekraczają pewne granice wyznaczane przez zasady sprawiedliwości dystrybutywnej ${ }^{44}$. Owa korekta, czyli nazwana inaczej pomoc państwa, powinna odbywać się jedynie w razie konieczności. Tak rozumiana zasada pomocniczości koresponduje, jak się wydaje, z charakterem ontologicznym oraz prawnym zasady subsydiarności, zaproponowanym przez

37 Tamże.

38 Tamże, s. 518.

39 J. Szymczyk, Odkrywanie wartości. Z problematyki socjologiczno-aksjologicznej, Polihymnia, Lublin 2004, s. 201.

40 W. Łużyński, Państwo pomocnicze, RW KUL, Lublin 2001, s. 73 nn.; J. Majka, Filozofia spoŁeczna, s. 171.

41 S. Kowalczyk, U podstaw demokracji. Zagadnienia aksjologiczne, RW KUL, Lublin 2001, s. 116.

42 E. Wnuk-Lipiński, Rynek nie sprzyja poetom, ale..., „Nowe Życie Gospodarcze” 1996, nr 38, s. 13.

43 E. Wnuk-Lipiński, Lewica, prawica?, „Credo” 1995, s. 18. Szerzej o rozumieniu sprawiedliwości społecznej oraz równości według E. Wnuka-Lipińskiego zob. Socjologia życia publicznego..., s. 60-69.

44 Tenże, Socjologia życia publicznego..., s. 54-55. 
C. Strzeszewskiego. Zdaniem E. Wnuka-Lipińskiego polityka społeczna w państwie demokratycznym powinna obejmować rożne działania w sferze publicznej, zmierzające do tego, by nierówności społeczne nie przekraczały takiego progu, poniżej którego pewne segmenty społeczeństwa zostałyby zmarginalizowane, a nawet wykluczone z udziału w życiu publicznym, natomiast inne segmenty, lepiej zorganizowane, burzyłyby pokój społeczny ${ }^{45}$. W tym kontekście interpretacja E. Wnuka-Lipińskiego jest zbieżna z zasadą społeczną o charakterze moralnym, przytaczaną przez C. Strzeszewskiego. Dla polskiego socjologa ważne jest też, żeby działania pomocowe państwa w postaci redystrybucji dóbr i usług nie obniżały efektywności systemu gospodarczego i nie zniechęcały do aktywności gospodarczej bardziej zaradnych członków społeczeństwa ${ }^{46}$. Co więcej, omawiany autor pełnienia funkcji pomocniczej nie wymaga jedynie od państwa, ale też od „uzupełniających struktur i sił społecznych. Jednakże państwo zawsze pozostaje siłą dominującą ${ }^{37}$. W takim rozumieniu zasady pomocniczości E. Wnuk-Lipiński nie jest odosobniony. Podobną opinię prezentuje m.in. Alicja Zygmunt, która uważa, że „państwo ma pełnić funkcję pomocniczą wobec działań jednostek, które to państwo ustanawiają, zaś tam, gdzie wymagana jest interwencja, decydującą rolę powinny odgrywać rodzina, społeczeństwo obywatelskie oraz wolny rynek" $^{\prime 4}$. Zasada pomocniczości dotyczy tylko okazjonalnej pomocy państwa, bez jego ustawicznej opiekuńczości.

\section{Solidarność społeczna}

Inną zasadą społeczną, do której odnosi się E. Wnuk-Lipiński, jest solidarność społeczna. O solidarności pisał już Emil Durkheim. Wyróżnił on „solidarność mechaniczną", opartą na podobieństwie, na wspólnocie uczuć i wierzeń, oraz „solidarność organiczną", opartą na współzależnościach, związaną ze zróżnicowaniem społecznym, indywidualizacją życia zbiorowego powstającą na

45 Tamże, s. 78.

46 Tamże.

47 Tamże.

48 A. Zygmunt, Zasada pomocniczości w nauczaniu Jana Pawła II, w: Zasada pomocniczości. Wymiar europejski, narodowy, regionalny i lokalny, red. A. Pawłowska, S. Grabowska, Wydawnictwo Uniwersytetu Rzeszowskiego, Rzeszów 2011, s. 43. Więcej o społeczeństwie obywatelskim oraz etycznym społeczeństwie obywatelskim E. Wnuk-Lipiński pisze w: Społeczeństwo obywatelskie a demokratyzacja, w: Zachowania polityczne, t. 2, red. R. Dalton, H.-D. Klingemann, Wydawnictwo Naukowe PWN, Warszawa 2010, s. 306-328. E. Wnuk-Lipiński, X. Bukowska, Społeczeństwo obywatelskie czy nieobywatelskie?, „Animacja Życia Publicznego” 2010, nr 1-2, s. 6-7; E. Wnuk-Lipiński, Etyczne społeczeństwo obywatelskie a upadek komunizmu i przejście do demokracji, w: O życiu publicznym, kulturze i innych sprawach, red. B. Mach, E. Wnuk-Lipiński, Collegium Civitas, Warszawa 2007, s. 11-30. 
skutek podziału pracy ${ }^{49}$. Kategorie solidarności zmieniają się, odzwierciedlając przemiany zachodzące między świadomością zbiorową a świadomością indywidualną. Według E. Durkheima, społeczeństwa o „solidarności mechanicznej” są homogeniczne, a ich świadomości pokrywają się, natomiast wraz ze wzrostem zróżnicowania społecznego, solidarność mechaniczna przekształca się w organiczną, a jednostki coraz bardziej usamodzielniają się, uwalniają spod wpływu zbiorowości. Nowy porządek i nowe zależności wynikają ze zróżnicowania i różnych specjalizacji ${ }^{50}$.

C. Strzeszewski stwierdza, że solidarność jest zasadą moralną, gdyż nakazuje ją prawo natury ze względu na społeczną naturę człowieka i konieczność społecznego dążenia do osiągania jego dobra, doskonałości osobowej ${ }^{51}$. Autor dodaje, że „pomocniczość porządkuje działalność społeczną, skierowując ją ku dobru osoby ludzkiej. Solidarność porządkuje działalność jednostek, zwracając ją ku dobru społecznemu" ${ }^{52}$. Stanowisko to podziela J. Szymczyk, konstatując, że moralny charakter zasady solidarności określa hierarchię wartości moralnych, nieodzownych zarówno w życiu osoby ludzkiej, jak i różnych grup społecznych, ze społecznością państwową włącznie ${ }^{53}$. J. Szymczyk pisze, że „przez solidarność rozumiemy przede wszystkim odpowiedzialność in solidum, to znaczy jednego za wszystkich, wszystkich za każdego i każdego za każdego. (...) Solidarność nie jest tylko sympatią, współczuciem, emocjonalnym zainteresowaniem losem bliźniego, lecz realnym zobowiązaniem i to zobowiązaniem ściśle określonym" ${ }^{54}$. Solidarność jako fakt społeczny to poszukiwanie konsensusu przy pewnych kompromisach oraz tworzenie autentycznej wspólnoty ${ }^{55}$.

E. Wnuk-Lipiński uwzględnia zasadę solidarności w swoich pracach, interpretując ją jako istotną wartość poprawnie funkcjonującego społeczeństwa. W swoich poglądach jest bliski koncepcji personalistycznej. Według niego „solidarność międzyludzka wymaga, aby ludziom (...) pomagać, zarówno w sensie bytowym, jak i w wymiarze psychologicznym" ${ }^{56}$. Warto w tym miejscu wspomnieć o zasadzie solidarności w kontekście polskiego ruchu „Solidarność”

49 E. Tarkowska, Durkheim Emile, w: Encyklopedia socjologii, t. 1, red. A. Kojder i in., Oficyna Naukowa, Warszawa 1998, s. 147.

50 Tamże, s. 147-148.

51 C. Strzeszewski, Katolicka nauka społeczna..., s. 523; tenże, Ewolucja katolickiej nauki społecznej, ODiSS, Warszawa 1978, s. 214.

52 Tenże, Katolicka nauka społeczna..., s. 521.

${ }^{53}$ J. Szymczyk, Dobro wspólne a prawa człowieka w ujęciu przedstawicieli lubelskiej szkoły katolickiej nauki społecznej..., s. 280-281.

54 Tenże, Elementy zasady solidarności w nauczaniu społecznym Jana Pawła II, „Chrześcijanin w Świecie" 1994, nr 2-3, s. 164.

55 Tamże, s. 165.

56 E. Wnuk-Lipiński, Granice wolności, pamiętnik polskiej transformacji, Wydawnictwo Naukowe Scholar/Collegium Civitas Press, Warszawa 2003, s. 334. 
z 1980 r. Dariusz Dobrzański uważa, że tutaj występowała ona łącznie z dwoma innymi zasadami: samorządności i polityki uprawianej bez odwoływania się do przemocy $^{57}$. Podobnego zdania jest E. Wnuk-Lipiński, według którego pierwszą „Solidarność" lat osiemdziesiątych cechowała kooperacja i kultura dialogu ${ }^{58}$. Są to czynniki potrzebne do zaistnienia zasady solidarności. Liczy się również „sens zbiorowy” określonej społeczności, czyli istniejąca w jej obrębie „prawda”, która - zdaniem omawianego autora - integruje i umożliwia sensowną komunikację społeczną ${ }^{59}$.

Należy dodać, że socjolog ten solidarność niekiedy analizuje w związku z walką o sprawiedliwość. Gdy w danym społeczeństwie występują problemy z funkcjonowaniem instytucji publicznych, istnieje poczucie relatywnej deprywacji ${ }^{60}$ i wtedy mogą pojawić się pewne działania solidarne. W takim ujęciu solidarność zawiera pozytywny komponent: z jej perspektywy obywatele motywują się wzajemnie do działania, walki o nowe prawa, uznania określonych wartości ${ }^{61}$. To właśnie te cechy konstytuowały polski ruch społeczny „Solidarność. W takim kontekście solidarność interpretuje E. Wnuk-Lipiński, według którego negacja i protest integrują ludzi, mobilizując ich do zachowań solidarnych ${ }^{62}$.

Warszawski socjolog, analizując kondycję polskiego społeczeństwa, pesymistycznie wypowiada się o współczesnej solidarności międzyludzkiej, która była istotnym składnikiem zachowań i postaw Polaków w latach osiemdziesiątych, a także składnikiem tradycyjnego etosu inteligenckiego, obecnie zaś zanika $^{63}$. Polskie społeczeństwo cechuje w III RP - jego zdaniem - rywalizacja i dychotomia, charakteryzująca się podziałami na „swoich”, czyli podobnych do siebie, i „obcych”, czyli ludzi korzystających z innych zestawów aksjologicznych lub konkurentów w wyścigu do osiągania dóbr ${ }^{64}$. E. Wnuk-Lipiński przestrzega też przed solidarnością wewnątrz grupy społecznej, która może przybrać formę patologii społecznej. Przykładami „wypaczonej solidarności” są np. grupy przestępcze, mafijne, sekty, ale też zachowanie tłumu, który pod

57 D. Dobrzański, Zasada solidarności. Studium z filozofii społecznej, Wydawnictwo Naukowe UAM, Poznań 2013, s. 86.

58 E. Wnuk-Lipiński, Granice liberalnej demokracji, „Znak” 2000, nr 1, s. 64.

59 Tamże.

60 E. Wnuk-Lipiński, Socjologia życia publicznego..., s. 65. Pojęcie deprywacji E. Wnuk-Lipiński rozumie jako zablokowanie możliwości zaspokajania jakiejś kategorii potrzeb. Deprywację względną interpretuje jako poczucie upośledzenia społecznego, które wywoływanie jest przez porównanie z jakimś punktem odniesienia. Autor uwzględnia tu widoczny układ nierówności i istnienie jakiejś zasady sprawiedliwości, którą ten układ nierówności narusza (tamże).

${ }^{61}$ Tenże, Granice liberalnej demokracji..., s. 64.

62 Tenże, Okragły Stół a procesy społeczne, w: Rok 1989. Nowa Polska, odmieniona Europa, red. A. Kojder, M. Gumowski, M. Karpiński, Instytut Lecha Wałęsy, Warszawa 1999, s. 270.

${ }^{63}$ Tenże, Elity i autorytety polskiej współczesności. Gdy przyzwoitość staniała, „Tygodnik Powszechny" 2001, nr 2, s. 3.

64 Tamże. 
wpływem emocji i instynktów przekracza normy społeczne ${ }^{65}$. Co więcej, autor podkreśla, że rozpadła się solidarność ogólnonarodowa na rzecz solidarności grupowych, charakteryzujących się wspólnotą interesów, a nie wartości. „Przeważa tolerancja dla «swoich» i rygoryzm moralny dla innych; egoizm grupowy i erozja myślenia w kategoriach «dobra wspólnego»"66. Spostrzeżenia E. Wnuka-Lipińskiego dotyczące solidarności Polaków są zatem pesymistyczne, choć należy podkreślić, że oparte na eksploracjach rzeczywistości społecznej i wynikające $\mathrm{z}$ doświadczenia.

\section{Zasada zaufania społecznego}

Do sfery wartości demokracji można również zaliczyć zasadę zaufania społecznego. E. Wnuk-Lipiński traktuje zaufanie jako postawę, którą analizuje $\mathrm{w}$ aspekcie ekonomicznym, politycznym i społecznym. Jeśli w społeczeństwie zaufanie jest niskie, to - zauważa - na każdej z tych płaszczyzn ponosi się duże koszty. W wymiarze ekonomicznym oznacza to, że każda umowa musi być ubezpieczona, wzrastają koszta kontroli i biurokracji. W wymiarze politycznym konkurentów traktuje się jak wrogów, co ogranicza współpracę. Z kolei w wymiarze społecznym obywatele nie są dla siebie przyjaźni, lecz nastawieni podejrzliwie ${ }^{67}$. Wszystkie wymienione czynniki mają niewątpliwy wpływ na jakość demokracji. Zaufanie, jak stwierdza często przywoływany przez E. Wnuka-Lipińskiego Robert Putnam, obok norm i powiązań jest częścią kapitału społecznego ${ }^{68}$. Polski socjolog zaufanie również traktuje jako element kapitału społecznego ${ }^{69}$. Natomiast jeśli chodzi o normy, to zdaniem R. Putnama „podtrzymują one społeczne zaufanie, ewoluują, zmniejszają koszta transakcji, ułatwiają współpracę" ${ }^{70}$. Najważniejszą z norm - według autora - jest odwzajemnianie, które dzieli on na: „zrównoważone” i „uogólnione” ${ }^{\text {"71 }}$. To pierwsze odnosi się do produktów o tej samej wartości, a drugie jest ciągłą wymianą dóbr, która w danym momencie nie odbywa się nas zasadzie rewanżu, ale

65 Tenże, Pierwotne hordy wśród nas, „Nowe Życie Gospodarcze” 1997, nr 16, s. 10.

${ }^{66}$ Tenże, Elity i autorytety polskiej współczesności..., s. 3; M. Wąs, Nie mamy czasu na solidarność, „Gazeta Wyborcza” 2010, nr 230, s. 4.

${ }^{67}$ Polska mała apokalipsa, [z Edmundem Wnukiem-Lipińskim rozmawiała Aleksandra Kaniewska], „Instytut Idei” 2014, nr 5, s. 12.

68 R. Putnam, Demokracja $w$ działaniu. Tradycje obywatelskie we współczesnych Włoszech, Wydawnictwo Znak, Kraków 1995, s. 258.

69 E. Wnuk-Lipiński, Socjologia życia publicznego..., s. 174; tenże, Demokratyczna rekonstrukcja..., S. 179.

70 R. Putnam, Demokracja w działaniu..., s. 266.

71 Tamże. 
opiera się na przeświadczeniu, że te usługi będą wynagradzane w przyszłości ${ }^{72}$. Norma uogólnionej wzajemności, jak zaznacza R. Putnam, jest produktywnym składnikiem kapitału społecznego. Społeczności, w których jest przestrzegana, mogą skuteczniej ograniczać oportunizm i rozwiązywać problemy związane z działaniem zbiorowym ${ }^{73}$. E. Wnuk-Lipiński nie określa normy uogólnionej wzajemności jako najważniejszego składnika kapitału społecznego, niemniej także bierze go pod uwagę, nazywając „domniemaniem wzajemności”74.

Jak stwierdzają różni autorzy, poziom zaufania oraz demokracja są ze sobą skorelowane. Piotr Sztompka przedstawia zestaw argumentów potwierdzających stanowisko, że zaufanie buduje demokrację ${ }^{75}$. Po pierwsze, demokracja wymaga komunikacji między obywatelami, a zaufanie ułatwia i sprzyja komunikacji. Po drugie, demokracja wymaga tolerancji, a zaufanie pomaga budować poczucie bezpieczeństwa i zmniejsza lęk przed różnicami. Po trzecie, demokracja zastępuje konflikt i walkę kompromisem oraz konsensem. Zaufanie pomaga akceptować reguły gry, a także zakłada dobrą wolę innych osób. Po czwarte, demokracja wymaga pewnego poziomu kultury w debacie publicznej, a zaufanie zapobiega pojawianiu się wrogości. Po piąte, demokracja wymaga partycypacji wyborczej, samorządowej, związkowej, a to obliguje do pewnego poziomu zaufania do ustroju politycznego, sprawiedliwych reguł, skuteczności działań obywateli. Po szóste, demokracja wymaga wyedukowanych obywateli i żeby posiąść kompetencje obywatelskie, ludzie muszą ufać źródłom informacji o polityce, mediom, danym statystycznym itp. ${ }^{76}$

Wśród Polaków występuje niedostatek kultury zaufania. E. Wnuk-Lipiński stoi wręcz na stanowisku, że „Polską chorobą jest brak zaufania”77. Autor twierdzi, że wynika to m.in. z pewnych doświadczeń odziedziczonych po okresie PRL, choć sam polemizuje $\mathrm{z}$ tak postawioną tezą. Według niego w latach osiemdziesiątych ubiegłego wieku społeczeństwo paradoksalnie miało powód, żeby sobie ufać, co było spowodowane istnieniem „Solidarności” i wspólnym celem, jakim było dobro Polski ${ }^{78}$. Okres transformacji, który charakteryzował się słabo rozwiniętym społeczeństwem obywatelskim oraz nastawieniem Polaków na maksymalizację indywidualnych korzyści, nie przyczynił się do zintensyfikowania zaufania społecznego. Agnieszka Pawłowska uważa, że „kapitał zaufania”, jakim Polacy obdarzyli rządy postsolidarnościowe, został roztrwoniony na skutek wysokiego

72 Tamże, s. 266-267.

73 Tamże, s. 267.

74 E. Wnuk-Lipiński, Socjologia życia publicznego..., s. 174.

75 P. Sztompka, Zaufanie. Fundament społeczeństwa, Wydawnictwo Znak, Kraków 2007, s. 354.

76 Tamże, s. 354-356.

77 Wnuk-Lipiński o największej chorobie Polaków - wzajemnej nieufności [z Edmundem Wnukiem-Lipińskim rozmawiała Aleksandra Kaniewska], www.polityka.pl (dostęp: 20.02.2014).

78 Polska mała apokalipsa..., s. 13. 
poziomu korupcji i niechęci elit politycznych do konsultowania podejmowanych decyzji ze społeczeństwem ${ }^{79}$. E. Wnuk-Lipiński twierdzi, że budowanie zaufania społecznego to długi proces, który łatwo zburzyć. W Polsce, w przeciwieństwie np. do Szwecji, gdzie poziom zaufania społecznego jest bardzo wysoki, brakuje budowanych z pokolenia na pokolenie stabilnych relacji społecznych ${ }^{80}$, co utrudnia funkcjonowanie demokracji. Wskaźniki poziomu społecznego zaufania od lat są bardzo niskie ${ }^{81}$. Dane z sondażu CBOS przeprowadzonego w $2014 \mathrm{r}$. wydają się potwierdzać obserwacje E. Wnuka-Lipińskiego dotyczące zaufania społecznego. W społeczeństwie polskim nieufność i ostrożność w nastawieniu do innych przeważa nad otwartością i ufnością. Z badań sondażowych wynika, że dość duże zaufanie Polaków w sferze prywatnej nie znajduje odzwierciedlenia w relacjach z osobami spoza najbliższego otoczenia. 55\% respondentów nie darzy zaufaniem nieznajomych ${ }^{82}$. Jeśli chodzi o zaufanie Polaków w sferze politycznej, również jest ono niskie. Tezę omawianego socjologa potwierdzają dane sondażowe z 2020 r., kiedy zaufanie np. do rządu zadeklarowało 46\% ankietowanych, do sejmu i senatu $33 \%$, a do partii politycznych jedynie $24 \%$ ankietowanych ${ }^{83}$.

Zaufanie społeczne można realizować na wiele sposobów, ale w obszarze życia publicznego, szczególnie ważnego dla E. Wnuka-Lipińskiego, w dużej mierze zależy to od władz wszystkich szczebli. Ich rolą jest porządkowanie przepisów prawa, stosowanie klarownych procedur administracyjno-instytucjonalnych czy ułatwianie wymiany gospodarczej. P. Sztompka wymienia determinanty kultury zaufania. Są to m.in.: dziedzictwo historyczne; aktualny kontekst strukturalny (przejrzystość organizacji społecznej, trwałość porządku społecznego, podporządkowanie władzy regułom prawa, realizowanie uprawnień i egzekwowanie obowiązków) oraz czynniki podmiotowe (rysy osobowościowe sprzyjające wytwarzaniu się uogólnionego zaufania) i zasoby kapitałowe (np. wykształcenie, majątek, znajomości, zdrowie $)^{84}$. E. Wnuk-Lipiński najbardziej podkreśla rolę polityków, którzy są grupą wzorotwórczą, silnie oddziałującą na kształtowanie się relacji społecznych. Jednak należy dodać, że również wskazuje na rolę obywateli, zwłaszcza na rozwój edukacji obywatelskiej w kierunku dbania o sprawy

79 A. Pawłowska, Wielopodmiotowość decydowania wyzwaniem dla kultury politycznej Polaków, w: Kultura polityczna Polaków. Przemiany, diagnozy, perspektywy, red. K. Janowski, Wydawnictwo Adam Marszałek, Toruń 2010, s. 73.

80 Polska mała apokalipsa..., s. 16; E. Wnuk-Lipiński, Civic Culture, Citizenship and the Quality of Democracy, „Studia Polityczne” 2010, nr 25, s. 18 nn.

81 S. Rudnicki, Zaufanie społeczne jako nowoczesna forma patriotyzmu i obywatelskości. Raport z badań i konspekt warsztatów, Wyższa Szkoła Europejska im. ks. Józefa Tischnera, Kraków 2008, s. 44.

${ }^{82}$ CBOS, Zaufanie w relacjach międzyludzkich. Komunikat z badań, luty, Warszawa 2014, s. 6.

${ }^{83}$ CBOS, Zaufanie społeczne. Komunikat z badań, kwiecień, Warszawa 2020, s. 3.

84 P. Sztompka, Zaufanie, w: Słownik socjologii, suplement, Oficyna Naukowa, Warszawa 2005, s. $430-431$. 
publiczne, czyli chodzi o zmianę mentalności z partykularnej na wspólnotową ${ }^{85}$, co z pewnością przyczyni się do wzrostu zaufania w społeczeństwie. Im wyższa kultura obywatelska ${ }^{86}$, tym większe zaufanie, a im większe zaufanie, tym bardziej rozwija się kultura obywatelska ${ }^{87}$.

\section{Zakończenie}

W niniejszym artykule przedstawiono wybrane zasady społeczne funkcjonujące w życiu społeczno-politycznym oraz stanowiska różnych autorów, ze szczególnym uwzględnieniem E. Wnuka-Lipińskiego, dotyczące tych zasad. Zauważono, że badacz bierze pod uwagę zasadę dobra wspólnego, którą rozpatruje z perspektywy zewnętrznej, społeczno-instytucjonalnej. W przeciwieństwie do P. Śpiewaka omawiany socjolog nie traktuje dobra wspólnego jako kategorii archaicznej, ale jako element rozwiniętych społeczeństw demokratycznych. Ponadto, podobnie jak dla przedstawicieli personalizmu społecznego oraz zwolenników idei republikańskiej, bonum commune nie jest dla niego zbiorem dóbr partykularnych, ale dobrem całej społeczności politycznej, czyli państwa. Spośród innych zasad społecznych E. Wnuk-Lipiński poświęca uwagę również zasadzie solidarności. W tym przypadku pozytywnie wspomina solidarność międzyludzką początku lat osiemdziesiątych ubiegłego wieku, która jednoczyła Polaków i mobilizowała do wspólnego działania przeciw wrogowi, jakim było ówczesne totalitarne państwo. Niestety, jak zauważa wspomniany autor, współczesna solidarność Polaków wydaje się być dysfunkcjonalna. Socjolog odnotowuje działalność grup patologicznych, niski poziom zaufania wśród ludzi, co negatywnie wpływa na stan polskiej poliarchii. Z analiz E. Wnuka-Lipińskiego zrekonstruować można także jego stanowisko na temat zasady pomocniczości, którą rozpatruje on w sposób pośredni, przedstawiając zadania i funkcje państwa. Uwagę poświęcił on również zaufaniu społecznemu, wskazując - na podstawie badań - na jego niski poziom wśród Polaków, nakreślając zarazem sposoby jego budowania i wzmacniania. Największa odpowiedzialność w tym zakresie spoczywa - jego zdaniem - na politykach, ale ogromną rolę odegrać także może, i powinna, edukacja obywatelska.

${ }^{85}$ Polska mała apokalipsa..., s. 17.

${ }^{86}$ Więcej o kulturze obywatelskiej u E. Wnuka-Lipińskiego: Socjologia życia publicznego..., s. 160-162.

87 Tamże, s. 161. 


\section{Bibliografia}

CBOS, Zaufanie w relacjach międzyludzkich. Komunikat z badań, luty, Warszawa 2014.

CBOS, Zaufanie społeczne. Komunikat z badań, kwiecień, Warszawa 2020.

Dobrzański D., Zasada solidarności. Studium z filozofii społecznej, Wydawnictwo Naukowe UAM, Poznań 2013.

Koperek J., Zasady życia społecznego, w: Słownik społeczny, red. B. Szlachta, WAM, Kraków 2004, s. 1604-1608.

Kowalczyk S., U podstaw demokracji. Zagadnienia aksjologiczne, RW KUL, Lublin 2001.

Krucina J., Dobro wspólne. Teoria i jej zastosowanie, Wydawnictwo Wrocławskiej Księgarni Archidiecezjlnej, Wrocław 1972.

Łużyński W., Państwo pomocnicze, RW KUL, Lublin 2001.

Majka J., Filozofia społeczna, ODiSS, Warszawa 1982.

Należy przywrócić ład moralny [z Edmundem Wnukiem-Lipińskim rozmawiali Amelia Łukasiak i Cezary Bielakowski], "Newsweek" 2005, nr 12, s. 26-27.

Pawłowska A., Wielopodmiotowość decydowania wyzwaniem dla kultury politycznej Polaków, w: Kultura polityczna Polaków. Przemiany, diagnozy, perspektywy, red. K. B. Janowski, Wydawnictwo Adam Marszałek, Toruń 2010, s. 61-74.

Polska mała apokalipsa [z Edmundem Wnukiem-Lipińskim rozmawiała Aleksandra Kaniewska], „Instytut Idei" 2014, nr 5, s. 12-18.

Putnam R., Demokracja w działaniu. Tradycje obywatelskie we współczesnych Włoszech, Wydawnictwo Znak, Kraków 1995.

Rudnicki S., Zaufanie społeczne jako nowoczesna forma patriotyzmu i obywatelskości. Raport z badań i konspekt warsztatów, WSE, Kraków 2008.

Schumpeter J.A., Kapitalizm, socjalizm, demokracja, Wydawnictwo Naukowe PWN, Warszawa 2009.

Strzeszewski C., Katolicka nauka społeczna, ODiSS, Warszawa 1985.

Strzeszewski C., Zasada a prawo społeczne, „Roczniki Nauk Społecznych” 1994-1994, nr 22-23, s. 137-141.

Szymczyk J., Elementy zasady solidarności w nauczaniu społecznym Jana Pawła II, „Chrześcijanin w Świecie" 1994, nr 2-3, s. 160-169.

Szymczyk J., Pojęcie zasady społecznej w kontekście dobra wspólnego w ujęciu przedstawicieli szkoły lubelskiej, ,Roczniki Nauk Społecznych" 1997, z. 1, s. 111-124.

Szymczyk J., Immanentny i instrumentalny aspekt dobra wspólnego, „Roczniki Nauk Społecznych” 1998, t. 26, z. 1, s. 157-170.

Szymczyk J., Dobro wspólne a prawa człowieka w ujęciu przedstawicieli lubelskiej szkoły katolickiej nauki społecznej, w: Pomiędzy etyka a polityką, red. E. Hałas, TN KUL, Lublin 1999, s. 277-297.

Szymczyk J., Odkrywanie wartości. Z problematyki socjologiczno-aksjologicznej, Polihymnia, Lublin 2004.

Szymczyk J., Rudymentarne wartości republikańskie. Zarys problematyki, w: Segmenty aktywności społecznej a wartości. Idee i praktyka, red. J. Szymczyk, Wydawnictwo KUL, Lublin 2012, s. 111-152.

Śpiewak P., Dobro wspólne to publiczna aktywność, w: Dobro wspólne. Gdański Aeropag - Forum Dialogu, 9-11 listopada 2001 Gdańsk, red. W. Bock, Biuro Prasowe Arcybiskupa Metropolity Gdańskiego, Gdańsk 2002, s. 70-73.

Sztompka P., Zaufanie. Fundament społeczeństwa, Wydawnictwo Znak, Kraków 2007.

Tarkowska E., Durkheim Emile, w: Encyklopedia socjologii, t. 1, red. A. Kojder i in., Oficyna Naukowa, Warszawa 1998, s. 144-151.

Wnuk-Lipiński o największej chorobie Polaków - wzajemnej nieufności [z Edmundem Wnukiem-Lipińskim rozmawiała Aleksandra Kaniewska], www.polityka.pl (dostęp: 20.02.2014).

Wnuk-Lipiński E., Lewica, prawica?, „Credo” 1995, s. 16-20. 
Wnuk-Lipiński E., Demokratyczna rekonstrukcja. Z socjologii radykalnej zmiany ustrojowej, Wydawnictwo Naukowe PWN, Warszawa 1996.

Wnuk-Lipiński E., Rynek nie sprzyja poetom, ale..., „Nowe Życie Gospodarcze” 1996, nr 38, s. 13.

Wnuk-Lipiński E., Pierwotne hordy wśród nas, "Nowe Życie Gospodarcze” 1997, nr 16, s. 10.

Wnuk-Lipiński E., Okragły Stół a procesy społeczne, w: Rok 1989. Nowa Polska, odmieniona Europa, red. A. Kojder, M. Gumowski, M. Karpiński, Instytut Lecha Wałęsy, Warszawa 1999, s. 261-271.

Wnuk-Lipiński E., Polityka, w: Encyklopedia socjologii, t. 3, red. H. Domański i in., Oficyna Naukowa, Warszawa 2000, s. 138.

Wnuk-Lipiński E., Granice liberalnej demokracji, „Znak" 2000, nr 1, s. 53-64.

Wnuk-Lipiński E., Elity i autorytety polskiej współczesności. Gdy przyzwoitość staniała, „Tygodnik Powszechny" 2001, nr 2, s. 3.

Wnuk-Lipiński E., Granice wolności, pamiętnik polskiej transformacji, Wydawnictwo Naukowe Scholar/Collegium Civitas Press, Warszawa 2003.

Wnuk-Lipiński E., Civic Culture, Citizenship and the Quality of Democracy, ,IStudia Polityczne" 2010, nr 25, s. 7-32.

Wnuk-Lipiński E., Czy w dzisiejszej Polsce istnieje zapotrzebowanie na roztropność?, w: Roztropność, red. Z. Bauman, D. Kowalczyk, E. Wnuk-Lipiński, J. Santorski [i in.], Forum Dialogu Gdański Areopag, Gdańsk 2011, s. 53-75.

Zygmunt A., Zasada pomocniczości w nauczaniu Jana Pawła Il, w: Zasada pomocniczości. Wymiar europejski, narodowy, regionalny i lokalny, red. A. Pawłowska, S. Grabowska, Wydawnictwo Uniwersytetu Rzeszowskiego, Rzeszów 2011, s. 40-52.

\section{Streszczenie}

W artykule wyjaśniono i przeanalizowano najważniejsze - w ujęciu Edmunda Wnuka-Lipińskiego - zasady życia społecznego. Uznano, że dużą wagę przywiązuje on do roli zasady dobra wspólnego. Ukazano też, że omawiany autor w swoich pracach bierze pod uwagę zasadę pomocniczości i rozpatruje ją przez pryzmat państwa. Socjolog istotną rolę w systemie demokratycznym przypisuje zasadzie solidarności, która tak znacząco jednoczyła, jego zdaniem, społeczeństwo polskie w latach osiemdziesiątych, w opozycji do reżimu komunistycznego. Po 1989 r. mamy - zdaniem autora - do czynienia z elementami atomizacji Polaków i rozwarstwienia społecznego. W kwestii zasady zaufania społecznego E. Wnuk-Lipiński również akcentuje niski jej poziom. Odpowiedzialnością za ten fakt obarcza przede wszystkim poczynania elit rządzących.

Słowa kluczowe: Edmund Wnuk-Lipiński, zasady życia społecznego, dobro wspólne, zasada pomocniczości, zasada solidarności, zaufanie społeczne

\section{Rudimentary Principles of Social Life According to Edmund Wnuk-Lipiński}

\section{Summary}

The article explains and analyses those principles of social life which Edmund Wnuk-Lipiński defines as of topical social significance. It is revealed that the sociologist attaches great importance to the principle of common good. It is also shown that in his works, Wnuk-Lipiński takes into account the principle of subsidiarity and approaches it from the perspective of state and statehood. The sociologist attributes an important role to the principle of solidarity in democratic systems. In his opinion, solidarity led the Polish society of the 1980s to unite in active resistance to the Communist regime. 
As argued by E. Wnuk-Lipiński, since 1989 we have been witnessing an axiological and sociological atomisation of the attitudes displayed by Poles, which has led to increased social stratification. In this context, the sociologist discusses the principle of social trust to argue that its level is extremely low in contemporary Polish society. E. Wnuk-Lipiński puts major responsibility for this fact on the ruling elites and their actions.

Key words: Edmund Wnuk-Lipiński, principles of social life, the common good, subsidiarity, solidarity, social trust 